\title{
The Management of Electro-Medical Equipment in Intensive Care Units: Assurance of Traceability and Metrological Reliability
}

\author{
Juliana Lins de Oliveira*; Herman Augusto Lepikson \\ Centro Universitário SENAI CIMATEC; Salvador, Bahia, Brazil
}

\begin{abstract}
Physiological measurements in the health sector have been supported by the rapid evolution of medical equipment technologies. The health sector increasingly requires the development of mechanisms and applications that assure the metrological reliability of the results obtained using the equipment for the diagnosis, treatment, and monitoring of the clinical evolution of patients. This study demonstrates the weaknesses in the control of metrological parameters related to electro-medical equipment (EMS) in Brazil, specifically those used in Intensive Care Units (ICU), where reliability is critical in terms of survival, sequelae or death. We discuss essential determinants to ensure physiological measurements, such as the limitations of legislation/standards, laboratory infrastructure, voluntary accreditations, including a brief history and indicators of patient safety in Brazil and the United States of America, as well as data from research at Hospital Units (HUs) located in Salvador, Bahia, Brazil.
\end{abstract}

Keywords: Metrology. Health. Electro-Medical Equipment. Intensive Care Unit.

The basic principles of metrology are essential to several branches of technology because it is the science of measurement and its applications [1].

Recent advances in this science inside industrial environments have brought countless benefits related to measurement and operation reliability, traceability, quality, and safety. These are characteristics which are neither wellestablished nor present inside the Brazilian hospital environment.

The development of instruments has contributed to the manufacture of increasingly modern electro-medical equipment with the advances in science and technology since the XX century. This development has enabled biomedicine to measure several physiological parameters in isolated or parallel ways.

Essential signals, such as body temperature, heart or pulse rates, blood pressure, breathing frequency, and oxygen saturation are measured uninterruptedly and the results are necessary to diagnose disease, evaluate the patient's general

Received on 18 February 2019; revised 7 March 2019.

Address for correspondence: Dr. Juliana Lins. Centro Universitário SENAI CIMATEC. Avenida Orlando Gomes, N. 1845 - Piatã Zip code: 41650-010; Salvador, Bahia, Brazil. E-mail: julianalins@gmail.com.

J Bioeng. Biotech. Appl. Health 2019;2(2):70-74

(C) 2019 by SENAI CIMATEC. All rights reserved. clinical status, to observe response to therapy and can be used to help in rapid decision-making by professionals in Intensive Care Unit (ICU) or Emergence Room (ER). It is because these signals and other physiological measurements determine the basis of clinical problem solving [2]. Patients are more susceptible to hospital infections and adverse events (AE) in an ER.

An $\mathrm{AE}$ is a situation that occurs during the treatment that is not defined by the patient's clinical conditions. An AE is not an error, neglect or poor quality. It means an unwanted care result related to therapy or diagnosis. An AE attached to a mistake is an avoidable adverse event [3].

Research performed at Harvard Medical School concluded more than $20 \%$ of the ER patients suffered an avoidable AE [4]. Avoidable AEs are the ones of the most important consequences of the lack or inadequacy of metrological control of EEM. Therefore, there is a need for precise measurements and with the Unit International System (UIS) traceability. There is also need a law to control the metrological management of the EEM, laboratory infrastructure with accreditations to competent organizations and users capable of understanding the bad functioning or measurement error in equipment.

The risk of using equipment without accurate metrological evaluation increased emphasis after 1990 as a result of the Harvard Medical Practice 
Study publication, in which standards for the quantification of health services were established. They showed that from a total of 30,195 hospitalizations in the United States of America (USA), 1,133 AEs registered were preventable [5]. From there, the community began to devote greater attention to AEs. In 2000, the publication of the report "to err is human" by the Institute of Medicine (IoM) estimated that about 44,000 to 98,000 annual deaths in the United States of America (USA) were due to the failure of medical assistance. Approximately 1 million patients admitted to US hospitals a year were victims of AE assistance, more than half of them from mistakes that could have been prevented [6].

In 2002, the first world debate on the subject took place, sponsored by the World Health Organization (WHO) at the 55 $5^{\text {th }}$ World Health Assembly: "Quality of Care: Patient Safety"; then, in 2004, the "World Alliance for Patient Safety" was launched by WHO, of which Brazil was a signatory. In 2013, the National Patient Safety Program (NPSP, by Ordinance GM No. 529/MS) was created in Brazil and the resolution of the Collegiate Board (RDC No. 36) of the National Health Surveillance Agency (ANVISA-Brazil) introduced the obligatory core creation of NPSP in health establishments [7] with the goal of passing the record and treat the AEs. The chronology of the reference points regarding AEs in the world and Brazil is described in Figure 1.

The competent agencies, such as WHO, IoM and ANVISA have since been debating and developing legislation for patient safety and health care related
AEs. WHO estimates that one in every 10 patients suffers damage when receiving medical care in developed countries, and in developing countries, the number of events is higher [7].

In Brazil, despite the recording of AEs being compulsory since 2014 , the number of records in the NPSP corresponds to only $1.1 \%$ of the medical institutions in the country. In the period of 20142018, the country registered 205,290 occurrences of AEs, and the ERs in the HUs sector recorded the second highest number [8].

The metrological control of EEM used in ERs, with calibrations and tests traced to IS ensures not only the safety, reliability, and accuracy required by a sector of high complexity for the care of patients at risk or severe, but also a reduction in the occurrence of avoidable AEs.

\section{Aspects of Certification and Metrological Control of EEM in Brazil}

No product of interest to health, national or imported, can be industrialized, offered for sale or handed over to the Brazilian market before being registered in the Ministry of Health in Brazil (Law n ${ }^{\circ}$ 6,360/1976). Law $n^{\circ}$ 9,782/1999 gives ANVISA the responsibility of regulation, control, and inspection of the products and services that involve risk to public health. This includes the granting of product registration (Law $\mathrm{n}^{\circ}$ 9,782/1999) [9]. Resolution $n^{\circ}$ 444/August 1999 from ANVISA established the model adopted to ensure the safety of medical electrical equipment (model), adopting the technical standards of NBR

Figure 1. Chronology of reference frames for AEs.

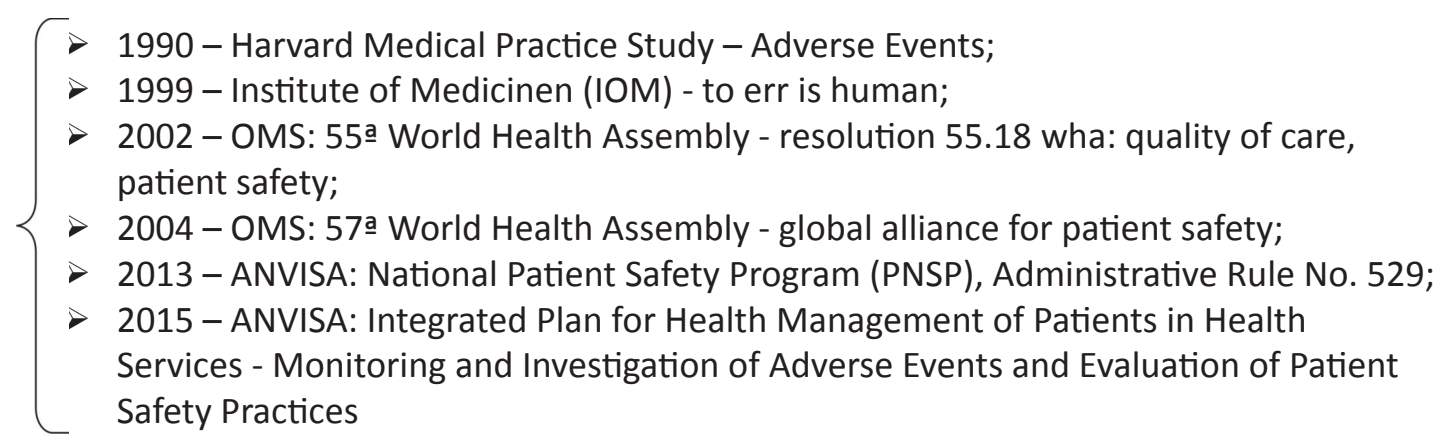


IEC 60,601 - 1 series: Electro-Medical Equipment. Part I - General Requirements for Safety; and Private Professional Standards -2. The compliance with the requirements established through the "good manufacturing practices for medical products" was determined for all suppliers of medical products by RDC 59/2000. The registry requirement from ANVISA grants certification of conformity to specific technical standards, issued by Certification Organizations for Products (COP) accredited by the National Institute of Metrology, Standardization and Industrial Quality (INMETRO-Brazil). The compliance results in the protection of the physical integrity of the users as well as the implementation of a good cycle between the regulator and productive systems [10].

The International Organization of Legal Metrology (IOLM) elaborates recommendations in which metrology is based on Technical Regulations for Measurement (TRM) prepared by INMETRO in Brazil. TRM puts several categories of measuring instruments, metrological and technical requirements for use and confirmation under central government control [11]. After delivery of any medical equipment to the customer, except for only clinical glass mercury thermometers, noninvasive mechanical aneroid sphygmomanometers and EEM used in the field of ionizing radiation, there is no law to regulate nor make compulsory metrological control tracing their performance over their life span. Currently, the only tool used in the direction of metrological reliability of EME in use is the voluntary accreditation of health establishments, which is conducted through national or international entities, including the International Standardization Organization (ISO), the National Accreditation Organization (NAO), the Joint Commission for Accreditation of Health Organizations (JCAHO), the American Association of Blood Banks (AABB). These entities are established agencies accredited to ensure the reliability of EEM, tracking calibrations as well as preventive and corrective maintenance [10].

According to the NationalSupplementary Health Agency (NSHA), by 2016, in Brazil, 133 hospitals had met important quality criteria as to the standard of care provided to the population. The data showed the performance of establishments according to three indicators: voluntary accreditation, hospital readmission, and patient safety. It was the first time that the NSHA offered information about the attributes of providers, helping consumers to monitor and evaluate the services received [12].

\section{About Survey}

The survey consisted of a literature review of theses, dissertations, and articles published in scientific meetings, journals, specialized journals, electronic consultation, analysis from ANVISA's reports and other relevant documents. There were also visits and questionnaires applied from May to July 2018 in UHs, of which two belong to SUS, and one is private, all located in Salvador, Bahia, Brazil. We searched for works that focus on the importance of metrology management of medical equipment of health, medical technology, metrology in health, adverse events in the hospital environment specifically in ERs, and legislation or specific standards.

\section{Results and Discussion}

There are 421 million hospitalizations annually and about 42.7 million AEs in the world. In the USA, these events are the third cause of death, reaching 400,000 deaths per year [13]. In 2002, a study in the United Kingdom showed that $28 \%$ of mercury sphygmomanometers and $42 \%$ of aneroides had errors of over $4 \mathrm{mmHg}$. The study also revealed that only one in every 54 physicians had taken the care to maintain and calibrate their sphygmomanometers [14]. INMETRO conducted a study of calibration verification of sphygmomanometers used in hospitals in Juiz de Fora, São Paulo, and Rio de Janeiro, in 1997. The results indicated that $61 \%$ of the checked sphygmomanometers had an error more significant than the maximum allowed, which is $4 \mathrm{~mm} \mathrm{Hg}$ [15]. In 2018, in Brazil, there were 321,321 health care establishments of different sizes [16] and only 3,401 SPs, which registered 205,290 AEs and 1,157 deaths/type of incidents from March/2014 
to May/2018. Bahia had 4,256 records. Of the total, 192,937 cases occurred in Hospital Unit (HUs), and 56,602 episodes occurred in UTIs [8] object of this study. A comparative study of three UHs was carried out in the city of Salvador, Bahia, one a member of a private network and two of the Unified Health System (SUS), all of them had ICUs, with 42.8 and 120 beds, respectively. None of them had a dedicated team for the metrological management of EEM, and only one had a member of staff with additional training in metrology. Two of them had regular maintenance and metrology management of EEM and intermediate checks in at least one hospital sector. Two had voluntary accreditation (ONA and QMENTUM) and only one registers AEs.

Brazil has 321,321 registered medical institutions and despite the compulsory creation of the NPSP, only 3,401 (1.1\%) take part in NPSP (1.1\%). This is taking into consideration that the NPSP provides unification in cases of several basic units in the same region. At best, with the unification of the number of establishments reduced to $50 \%$, the country should have approximately 161,000 NPSPs, which means that the real number of EAs in the country is far higher than what is known today. Despite the lack of reporting AEs, the ERs were the second type of service to register the highest rates over the last four years, accounting for $29.3 \%$ of incidents attributed to hospitals. If we assume that only $10 \%$ of these incidents are caused by failures or absence of metrological control of EEM, this would already indicate 5,660 incidents which could have been avoided. The survey also shows that no law or regulation makes the metrological control of EEM compulsory after commercialization in Brazil, nor any network of qualified laboratories and calibration service providers and tests that could meet the demand [10]. Furthermore, a set of actions that promote the further training in Metrology for users/ managers is necessary, EEM in the dissemination of metrology culture, HUs health metrology, indepth studies for the determination of uncertainty of measurement and other metrological parameters to promote error prevention in any sector.

\section{Acknowledgment}

To God, my family and my Prof. Dr. Herman A. Lepikson.

\section{References}

1. INMETRO. Vocabulário Internacional de Termos Fundamentais e Gerais de Metrologia - VIM, Portaria 029 de 1995, 3ª . Edição, 2012.Disponível em <http:// www.inmetro.gov.br/inovacao/publicacoes/vim_2012. pdf $>$, acessado em 15/05/2018.

2. Potter, P. Ann Fundamentos de enfermagem / Patricia A. Potter, Anne Griffi n Perry; [tradução de Maria Inês Corrêa Nascimento et al.]. - Rio de Janeiro: Elsevier, 2009. $7^{\mathrm{a}}$ ed. Pg 503.

3. Reason, J. Human error: models and management. BMJ. 2000;320(7237):768-70.

4. Mendes, W., Pavão, A.L.B., Martins, M., Moura, M.L.O., Travassos, C. 2013.

5. Brennan, T.A., Leape, L.L., Laird, N.M., et al. Incidence of adverse events and negligence in hospitalized patients: results of the Harvard Medical Practice Study I. N Engl J Med. 1991;324:370-6.

6. Kohn, L.T., Corrigan, J.M., Donaldson, M.S., et al. To err is human. Washington, DC: National Academy Press; 2000.

7. Caderno 7 ANVISA - Gestão de riscos e investigação de eventos adversos relacionados à assistência à saúde. Brasília, 2017.

8. Agência Nacional de Vigilância Sanitária. Relatório dos Estados, Eventos Adversos. Disponível em: https:// www20.anvisa.gov.br/segurancadopaciente/index.php/ publicacoes/category/relatorios-dos-estados $>$ Acesso em 26 de jun.2018.

9. Manual de Regularização de Equipamentos Médicos na ANVISA, 2017, disponível em<http://portal.anvisa. gov.br/documents/33912/264673/Manual+para+regul ariza $\% \mathrm{C} 3 \% \mathrm{~A} 7 \% \mathrm{C} 3 \% \mathrm{~A} 3 \mathrm{o}+\mathrm{de}+$ equipamentos $+\mathrm{m} \% \mathrm{C} 3$ $\%$ A9dicos+na+Anvisa/ > acessado em 18 de julho de 2018.

10. Monteiro, E.C., Lessa, M.L.Ametrologia na área da saúde: garantia da segurança e da qualidade dos equipamentos eletromédicos. Pontifícia Universidade Católica do Rio de Janeiro - Programa de Pós-Graduação em Metrologia (Pós-MQI). Engevista 2005:52.Disponível em <http:// www.uff.br/engevista/2_7Engevista05.pdf.> Acessado em 15/05/2018.

11. Menezes, C.I.C., Salles, M.T., Silva, M.A.S. Uma Ferramenta para melhoria da Qualidade dos Instrumentos da Área da Saúde. Metrologia-2003 - Metrologia para a Vida Sociedade Brasileira de Metrologia (SBM). 2003:1-7. 
12. Lista de hospitais com acreditação máxima, disponível em<http://www.ans.gov.br/aans/noticias-ans/qualidade-dasaude/3245-ans-divulga-lista-de-hospitais-que-atendemcriterios-de-qualidade>, acessado em 20/07/2018.

13. Makary, M.A., Daniel, M. Medical error - the third leading cause of death in the US. BMJ. 2016;2139(353):1-5.

14. Waugh, J.J., et al. Hidden errors of aneroid sphygmomanometers. Blood Press Monit 2002;7:309-12.
15. Instituto Nacional de Metrologia, Normalização e Qualidade Industrial. Esfigmomanômetros. Disponível em <http://www.inmetro.gov.br/ consumidor/produtos/esfigmo.asp $>$.Acesso em 17 de ag. 2018.

16. Datasus. Disponível em: <http://cnes2.datasus.gov. br/Mod_Ind_Unidade.asp? VEstado $=00>$ Acesso em 20 de jun. 2018 . 